\title{
EDITOR'S NOTE: THE ECONOMIC WAR AND THE SILENCE OF THE ACADEMY
}

\section{Paulo Fagundes Visentini ${ }^{1}$}

The last several years have been characterized by a growing acceleration of International Relations. With the end of the Cold War, amidst the Gorbachev government, the fall of the Eastern European socialist regimes in 1989 and the disintegration of the Soviet Union in 1991, there was room for a reordering of forces in the world-system. When the vacuum started to be occupied by old and new international players, the situation turned into a War of Positions. China and the other emerging nations, especially the members of BRICS, were able to gain more leverage. But this precarious balance was significantly affected by the economic crisis of OECD (Organization for Economic Cooperation and Development) countries since 2008-09.

This phenomenon was combined with U.S. failure in its War on Terror in Middle East and Central Asia. However, the Euro-American reaction did not take long for trying to restore the statu quo ante. The developments of the "Arab Spring" constituted the first stage of a domino counter-offensive (sometimes accompanied by military escalation), which continued with the Western projection of power in Africa (second stage), a continent whose position was being altered due to the cooperation with emerging powers. The third stage resulted from the increasing tensions on Eastern Asia, which China has been able to neutralize so far, but that are still growing. The fourth stage of the

${ }^{1}$ Professor of International Relations at Universidade Federal do Rio Grande do Sul. PhD in Economic History, Universidade de São Paulo. Director of the Brazilian Centre for Strategy and International Relations (NERINT). E-mail: paulovi@ufrgs.br. 
escalation is directed against Vladimir Putin's Russia through the Ukrainian conflict.

Local conflicts and regional strains have been receiving a post factum attention from the Academy, in a dissociate form. We are lacking a comprehensive thought that will be able to well understand current affairs in a coherent framework. All these episodes seem confusing, but not as much as the academy, that is dealing with them as specific and atypical phenomena. Therefore, the silence of the academy regarding all the turmoil of these processes calls our attention.

When one takes into account the events that took place in Brazil, since the demonstrations of June 2013, passing through the World Cup till the presidential elections and the weakening of Brazilian internationalized companies (private and public ones) hit by a unusual wave of corruption accusations, the fifth stage of the general reaction can be identified. It also affects Argentina, Venezuela and the induced pressure for the decrease in oil prices. This phase is heavily applying the so-called smart power. And its motivation seems to be primarily economic.

The difficult economic and international recovery of the North Atlantic powers has been achieved at the expense of the monetary reserves and estate of emerging powers. The growing anti-BRICS discourse is associated to this phenomenon. There is a true Economic $W$ ar in course that is the guiding thread that integrates present-day conflicts and tensions. It is accompanied by a cleverly engineered geopolitical realignment, by the United States and the United Kingdom, aiming to articulate an Atlantic geoeconomic space capable of regaining ground towards the Pacific.

However, the geopolitical dimension can only be considered as a result of the growing economic competition that is in course. It is a phenomenon that deserves the attention of analysts in the mark of World War I's centenary outbreak. Surely, the world is different and history does not repeat itself. But the silence of the academy regarding the economic fundamentals of the current conflicts, maneuvers and strains may lead it to be apart from history. The world is changing from a War of Positions to a War of Movement. 


\section{Paulo Fagundes Visentini}

We thank the Office of Research of the Deanship of Universidade Federal do Rio Grande do Sul, which, through the Support Program for Journal Editing (PAEP), supported the translation work, as well as the whole team that worked on editing and translating this number, especially Edition Assistant Pedro Alt and Prof. Cristina Pecequilo, for a final revision of the translated versions of the articles. We are also pleased to inform that the Brazilian Centre for Strategy and International Relations (NERINT), co-editor of Austral, and the Brazilian Centre for African Studies (CEBRAFRICA), were relocated to the Faculty of Economics of the Universidade Federal do Rio Grande do Sul, shortly after its fifteenth anniversary, beginning a new phase. 